\title{
IMPLEMENTASI PENDIDIKAN KARAKTER \\ DALAM PEMBELAJARAN AQIDAH AKHLAK \\ (Studi Multi Kasus di MIN Sekuduk dan MIN Pemangkat \\ Kabupaten Sambas)
}

Purniadi Putra

PGMI FITK IAIS Sultan Muhammad Syafiuddin Sambas

Email: usupurniadi@yahoo.com

\begin{abstract}
ABSTRAK
Latar belakang penelitian ini adalah kegelisahan peneliti terhadap karakter bangsa yang sedang mengalami dekadensi moral, di antaranya adalah meningkatnya pergaulan bebas, penyalahgunaan obat-obatan, dan lain sebagainya. Dalam hal ini sekolah khususnya dalam pembelajaran Aqidah Akhlak memiliki peran besar dalam penyadaran nilai-nilai agama Islam kepada peserta didik. Penelitian ini menggunakan metode kualitatif. Lokasi penelitian di MIN Sekuduk dan MIN Pemangkat Kabuaten Sambas. Pengumpulan data dilakukan dengan observasi, wawancara, dan dokumentasi. Analisis data dilakukan dengan analisis lintas kasus. Hasil penelitian menunjukkan bahwa: (1) perencanaan pembelajaran guru Aqidah Akhlak sebagai upaya pembentukan karakter adalah dengan mendesain perencanaan pembelajaran dengan melibatkan media, (2) penerapan pembelajaran guru Aqidah Akhlak dalam upaya pembentukan karakter siswa yang dilakukan telah mengacu pada tata tertib maupun aturan yang telah direncanakan dan ditetapkan dalam setiap kegiatan atau proses pembelajaran dalam lembaga pendidikan dasar/MI, (3) evaluasi pembelajaran guru Aqidah Akhlak biasanya berupa ujian tugas dari guru, ulangan harian, nilai UTS dan ulangan UAS siawa. Penyampaian pembelajaran Aqidah akhlak dalam pembentukan karakter siswa yang diterapkan oleh guru mata pelajaran dari masing lokasi penelitian tersebut membuahkan hasil yang sangat memuaskan.
\end{abstract}

Kata kunci: Pendidikan Karakter, Pembelajaran Aqidah Akhlak di MI

\begin{abstract}
The background of this research is: researcher's anxiety towards the character of the nation that is experiencing moral decadence, such as increasing free association, drug abuse, and so forth. In this case the school especially in the learning of Akidah Akhlak have a big role in the awareness of Islamic religious values to learners. This research uses qualitative method. Research location in MIN Sekuduk and MIN Pemangkat Kabuaten Sambas. Data collection is done by observation, interview, and documentation. Data analysis was done by cross-case analysis. The result of
\end{abstract}

AL-BIDAYAH: Jurnal Pendidikan Dasar Islam

Volume 9, Nomor 02, Desember 2017; ISSN: 2085-0034 
the research shows that: (1) learning planning of Aqidah Akhlak as an effort of character building is by designing lesson planning by involving Media, (2) application of teacher learning of Aqidah Akhlak in effort of character building of student which done have referring to order or rule which have Planned and determined in every activity or learning process in Basic education institution/ MI, (3) evaluation of teacher learning of Aqidah Akhlak usually in the form of examination of task from teacher, daily test, UTS value and UAS saswa test. Submission of learning Aqidah morals in the formation of student characters in applied by the subject teachers from each location of the study led to very satisfactory results.

\section{Keywords: Character Education, Learning Aqidah Morals in MI}

\section{PENDAHULUAN}

Dewasa ini banyak pihak menuntut peningkatan intensitas dan kualitas pelaksanaan pendidikan karakter pada lembaga pendidikan formal. Tuntutan tersebut didasarkan pada fenomena sosial yang berkembang, yakni meningkatnya kenakalan remaja dalam masyarakat, seperti perkelahian massal dan berbagai kasus dekadensi moral lainnya. Bahkan di kota-kota besar tertentu, gejala tersebut telah sampai pada taraf yang sangat meresahkan. Oleh karena itu, lembaga pendidikan formal sebagai wadah resmi pembinaan generasi muda diharapkan dapat meningkatkan peranannya dalam pembentukan kepribadian peserta didik melalui peningkatan intensitas dan kualitas pendidikan karakter.

Pendidikan mempunyai peranan penting dalam membangun kecerdasan sekaligus kepribadian anak manusia menjadi lebih baik. Oleh karena itu, pendidikan secara terusmenerus dibangun dan dikembangkan agar dari proses pelaksanaan menghasilkan generasi yang diharapkan. Dalam rangka menghasilkan peserta didik yang unggul dan diharapkan, proses pendidikan juga senantiasa dievaluasi dan diperbaiki. Salah satu upaya perbaikan kualitas pendidikan adalah melalui pendidikan karakter. ${ }^{44}$

Karakter merupakan nilai dasar yang membangun pribadi seseorang, terbentuk baik karena pengaruh hereditas maupun pengaruh lingkungan, yang membedakannya dengan orang lain, serta diwujudkan dalam sikap dan perilakunya dalam kehidupan sehari-hari. ${ }^{45}$

Sedangkan orang yang berkarakter adalah orang yang dapat merespon segala situasi secara bermoral dan dimanifestasikan dalam bentuk tindakan nyata melalui tingkah laku yang baik. Menurut Lickona, karakter berkaitan dengan konsep moral (moral knowing), sikap moral (moral felling), dan perilaku moral (moral behavior). ${ }^{46}$

Berdasarkan ketiga komponen ini dapat dinyatakan bahwa karakter yang baik didukung oleh pengetahuan tentang kebaikan, keinginan untuk berbuat baik, dan melakukan perbuatan

44 Akhmad Muhaimin Azzet, Urgensi Pendidikan Karakter di Indonesia, (Yogyakarta: Ar-Ruzz Media 2011)

45 Muchlas Samani, dan Hariyanto, M.S, Konsep Dan Model Pendidikan Karakter. (Bandung: PT Remaja Rosdakarya Offset, 2011), hlm 43.

46 Ibid, hlm 50. 
kebaikan. Bagan di bawah ini merupakan bagan keterkaitan ketiga kerangka pikir ini.

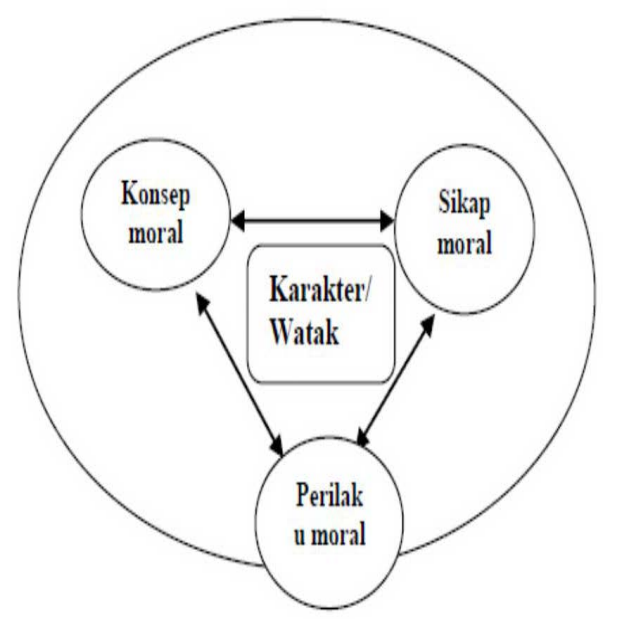

\section{Gambar: Keterkaitan Antara Komponen Moral Dalam Rangka Pembentukan Karakter yang baik menurut Lickona}

Pendidikan karakter adalah suatu sistem penanaman nilai-nilai karakter yang baik kepada semua yang terlibat dan sebagai warga sekolah sehingga mempunyai pengetahuan, kesadaran, dan tindakan dalam melaksanakan nilai-nilai tersebut. ${ }^{47}$

Menurut Fakry Gaffar pendidikan karakter merupakan sebuah proses transformasi nilainilai kehidupan untuk ditumbuhkembangkan dalam kepribadian seseorang sehingga menjadi satu dalam perilaku kehidupan orang itu. Dalam definisi tersebut ada tiga pikiran penting, yaitu:

a. Proses transformasi nilai-nilai

b. Ditumbuhkembangkan dalam kepribadian, dan

c. Menjadi satu dalam perilaku.

Pendidikan karakter di sekolah sebagai pembelajaran yang mengarah pada penguatan dan pengembangan perilaku anak secara utuh

47 Akhmad Muhaimin Azzet, Urgensi Pendidikan Karakter di Indonesia, (Yogyakarta: Ar-Ruzz Media 2011), hlm 36. yang didasarkan pada suatu nilai tertentu yang dirujuk oleh sekolah. Jadi pendidikan karakter di sekolah mengandung makna:

a. Pendidikan karakter merupakan pendidikan yang terintegrasi dengan pembelajaran yang terjadi pada semua mata pelajaran

b. Diarahkan pada penguatan dan pengembangan perilaku anak secara utuh. Asumsinya anak merupakan organisme manusia yang memiliki potensi untuk dikuatkan dan dikembangkan

c. Penguatan dan pengembangan perilaku didasari oleh nilai yang dirujuk sekolah (lembaga).

Tujuan pendidikan karakter di sekolah $\operatorname{adalah}^{48}$ :

a. Menguatkan dan mengembangkan nilai-nilai kehidupan yang dianggap penting dan perlu sehingga menjadi kepribadian atau kepemilikan peserta didik yang khas sebagaimana nilai-nilai yang dikembangkan.

b. Mengoreksi perilaku peserta didik yang tidak bersesuaian dengan nilai-nilai yang dikembangkan oleh sekolah.

c. Membangun koneksi yang harmoni dengan keluarga dan masyarakat dalam memerankan tanggung jawab pendidikan karakter secara bersama.

Pendidikan karakter kini memang menjadi isu utama dalam pendidikan. Selain menjadi bagian dari proses pembentukan akhlak anak bangsa, pendidikan karakter diharapkan mampu menjadi pondasi utama dalam meningkatkan derajat dan martabat bangsa Indonesia. Dalam

48 Kesuma, Dharma dkk., Pendidikan Karakter Kajian Teori dan Praktek di Sekolah. (Bandung: PT Remaja Rosdakarya, 2011), hlm 5. 
lingkungan Kementerian Pendidikan Nasional sendiri, pendidikan karakter menjadi fokus pendidikan di seluruh jenjang pendidikan yang dibinannya

Dalam Canadian Journal of School Psychology edisi April 2005, dua orang peneliti dari Universitas Calgary, Dr Tanya Beran dan Dr Leslie Tutty menemukan bahwa setengah dari jumlah siswa dalam penelitian mereka pernah mengalami intimidasi dan siswa di kelas 1 sampai 3 diintimidasi sama seringnya dengan siswa kelas 4 sampai 6. Peneliti dari Selandia Baru, Lind dan Maxwell, menemukan bahwa 90\% kejadian-kejadian penyiksaan emosi dan kekerasan fisik di antara anak-anak terjadi di sekolah. Tidaklah mengherankan bahwa kebijakan toleransi nol terhadap perilaku intimidasi telah menyebar ke seluruh dunia. ${ }^{49}$

Dari data yang mengejutkan tersebut, dirasa sangat perlu untuk mengubah dan memperbaiki karakter generasi emas pada masa mendatang. Tentunya diharapkan pendidikan karakter mampu untuk mengubah generasi selanjutnya menjadi generasi yang berkarakter baik.

Demoralisasi terjadi karena proses pembelajaran cenderung mengajarkan pendidikan moral dan budi pekerti sebatas teks dan kurang mempersiapkan siswa untuk menyikapi dan menghadapi kehidupan yang kontradiktif. Selain itu, pendidikan agama yang selama puluhan tahun dianggap sebagai salah satu media efektif dalam penginternalisasian karakter luhur terhadap anak didik, ditulis oleh Agus Wibowo (2008), dalam kenyataannya sekadar mengajarkan dasar-dasar agama. ${ }^{50}$

49 Parsons, Les, (2009), Bullied Teacher Bullied Student, terj. Grace Worang, Jakarta: Grasindo, 2009), hlm 3.

50 Agus Wibowo, Pendidikan Karakter: Strategi Membangun Karakter Bangsa Berperadaban, (Yogyakarta: Pustaka Belajar, 2012), hlm 55.
Bahkan ia semakin kehilangan perannya sebagai media mengantarkan siswanya untuk memahami dan mengamalkan ajaran agamanya.

Dalam kehidupan sehari-hari akhlak merupakan hal yang sangat penting dalam bertingkah laku. Dengan akhlak yang baik seseorang tidak akan terpengaruh pada hal-hal yang negatif. Dalam agama Islam telah diajarkan kepada semua pemeluknya agar dirinya menjadi manusia yang berguna bagi dirinya serta berguna bagi orang lain. Manusia yang berakhlak akan dapat menghiasi dirinya dengan sifat kemanusiaan yang sempurna, menjadi manusia shaleh dalam arti yang sebenarnya, selalu menjaga kualitas kepribadiannya sesuai dengan tuntunan Allah SWT dan Rasul-Nya.

Aqidah adalah bentuk masdar dari kata aqoda, ya'qidu, 'aqdan-, aqidatan yang berarti simpulan, ikatan, sangkutan, perjanjian dan kokoh. Sedang secara teknis aqidah berarti iman. Tugas pendidikan karakter selain mengajarkan mana nilai-nilai kebaikan dan mana nilai-nilai keburukan, justru yang ditekankan adalah langkah-langkah penanaman kebiasaan (habituation) terhadap hal-hal yang baik. Hasilnya, individu diharapkan mempunyai pemahaman tentang nilai-nilai kebaikan dan nilai keburukan, mampu merasakan nilai-nilai yang baik dan mau melakukannya kepercayaan dan keyakinan. Dan tumbuhnya kepercayaan tentunya di dalam hati, sehingga yang dimaksud aqidah adalah kepercayaan yang menghujam atau tersimpul di dalam hati. ${ }^{51}$

Menurut istilah aqidah adalah hal-hal yang wajib dibenarkan oleh hati dan jiwa merasa tenteram kepadanya, sehingga menjadi keyakinan kukuh yang tidak tercampur oleh

51 Muhaimin Tadjab Abd Mujib, (1994), DimensiDimensi Studi Islam. (Surabaya: Karya Abditama, 1994), hlm 241-242. 
keraguan..$^{52}$

Pengertian akhlak secara etimologi menurut Muhaimin Tadjab, Abd. Mujib ${ }^{53}$ berasal dari kata Khuluq dan jamaknya Akhlaq, yang berarti budi pekerti, etika, moral. Demikian pula kata Khuluq mempunyai kesesuaian dengan Khilqun, hanya saja khuluq merupakan perangai manusia dari dalam diri (ruhaniah) sedang khilqun merupakan perangai manusia dari luar (jasmani). Ibnu Maskawaih dalam bukunya Tahdzibul Akhlak Wa That-hirul A'raq mendefinisikan akhlak dengan keadaan gerak jiwa yang mendorong ke arah melakukan perbuatan dengan tidak memerlukan pikiran. ${ }^{54}$

Dengan demikian pembelajaran aqidah akhlak adalah upaya sadar dan terencana dalam menyiapkan peserta didik untuk mengenal, memahami, menghayati dan mengimani kepada Allah SWT dan merealisasikannya dalam perilaku akhlak mulia dalam kehidupan seharihari berdasarkan Qur'an dan hadits melalui kegiatan bimbingan, pengajaran, latihan, serta penggunaan pengalaman. Dibarengi tuntutan untuk menghormati penganut agama lain dan hubungannya dengan kerukunan antar umat beragama dalam masyarakat hingga terwujud kesatuan dan persatuan bangsa.

Hal serupa diungkapkan oleh Hery Noer Aly dan Munzier bahwa orientasi akhlak keagamaan merupakan sesuatu yang asasi di dalam pendidikan Islam. Seruan agar berakhlak mulia, menjunjung tinggi hidayah

52 Abdullah bin Abdil Hamid al-Atsari, Panduan Aqidah Lengkap. (Bogor: Pustaka Ibnu Katsir, 2005), hlm 28.

53 Mujib, Abd, Muhaimin Tadjab, Dimensi-Dimensi Studi Islam. (Surabaya: Karya Abditama, 1994), hlm 243.

54 Muhaimin Tadjab Abd Mujib, Dimensi-Dimensi Studi Islam. (Surabaya: Karya Abditama, 1994), hlm 243. dan berbudi pekerti luhur sebagaimana dimuat dalam al-Qur'an, hadits Rasulullah SAW dan sumber-sumber primer warisan budaya Islam melegitimasi keutamaan orientasi tersebut. ${ }^{55}$

Pembelajaran Akidah Akhlak merupakan mata pelajaran yang memiliki kontribusi besar dalam memberikan motivasi kepada peserta didik untuk mempelajari dan mempraktikkan akidahnya dalam bentuk pembiasaan untuk melakukan akhlak terpuji dan menghindari akhlak tercela dalam kehidupan sehari-hari. Al-akhlak al-karimah ini sangat penting untuk dipraktikkan dan dibiasakan oleh peserta didik dalam kehidupan individu, bermasyarakat dan berbangsa, terutama dalam rangka mengantisipasi dampak negatif dari era globalisasi dan krisis multidimensional yang melanda bangsa dan Negara Indonesia. Jadi, dalam penelitian ini, penulis hanya akan melakukan penelitian pada mata pelajaran Aqidah Akhlak.

Sementara itu, di MIN Sekuduk dan MIN Pemangkat Kabupaten Sambas sebagai sekolah yang berasaskan agama Islam juga mempunyai problema dalam hal akhlak peserta didik. Misalnya, mulai tampak tindakan kurang rukun terhadap temannya, membohongi gurunya, kurang sopan terhadap gurunya, dan sebagainya. Dengan demikian, pendidikan akhlak sejak dini pada peserta didik sangatlah penting sekali agar peserta didik terbiasa bersikap sopan dan selalu berbuat hal-hal terpuji lainnya dalam kehidupan bermasyarakat baik pada saat masih usia sekolah maupun pada saat mereka besar nanti. Pembentukan karakter di sini sangat ditekankan karena penanaman pribadi yang baik sejak dini akan memberikan dampak pada

55 Hery Noer Aly dan Munzier, Watak Pendidikan Islam, (Jakarta Utara: Friska Agung Insani, cet. III, 2008), hlm 149. 
masa-masa selanjutnya.

Melihat permasalahan di atas, penulis tertarik untuk membahas dalam jurnal ini dengan judul "Implementasi Pendidikan Karakter dalam Pembelajaran Aqidah Akhlak (studi multi kasus di MIN Sekuduk dan MIN Pemangkat Kabupaten Sambas). Adapun fokus penelitian jurnal ini adalah (a) bagaimana perencanaan pembelajaran guru Aqidah Akhlak sebagai upaya pembentukan karakter siswa di MIN Sekuduk dan MIN Pemangkat di Kabupaten Sambas?, (b) bagaimana penerapan pembelajaran guru Aqidah Akhlak dalam upaya pembentukan karakter siswa di MIN Sekuduk dan MIN Pemangkat di Kabupaten Sambas? dan (c) bagaimana evaluasi pembelajaran guru Aqidah Akhlak sebagai upaya pembentukan karakter siswa di MIN Sekuduk dan MIN Pemangkat di Kabupaten Sambas?.

\section{METODE PENELITIAN}

Sesuai dengan permasalahan yang menjadi fokus dalam penelitian yang berjudul "Implementasi Pendidikan Karakter dalam Pembelajaran Aqidah Akhlak di MIN Sekuduk dan MIN Pemangkat", maka pendekatan penelitian yang digunakan adalah pendekatan kualitatif. Pendekatan kualitatif adalah pendekatan dengan maksud untuk mendiskripsikan fenomena, peristiwa, aktivitas sosial, sikap, kepercayaan, persepsi, dan pemikiran orang baik secara individu maupun kelompok. ${ }^{56}$

Lokasi penelitian terletak di Madrasah Ibtidaiyah Negeri Sekuduk dengan alamat desa Sekuduk Kecamtan Sambas sedangkan Madrasah Ibtidaiyah Negeri Pemangkat

56 Nana Syaodih Sukmadinata, Metode Penelitian Pendidikan. (Bandung: PT Rosda Karya, 2007), hlm 60. keberadaan di alamat Jalan Penjajap Kecamatan Pemangkat Kabupaten Sambas.

Adapun teknik analisis data lintas kasus yang dilakukan dalam menganalisis lintas kasus ini meliputi: 1) menggunakan pendekatan induktif konseptualistik yang dilakukan dengan membandingkan dan memadukan temuan konseptual dari masing-masing kasus individu; 2) hasilnya dijadikan dasar untuk menyusun pernyataan konseptual atau proposisi-proposisi lintas kasus 3) mengevaluasi kesesuaian proposisi dengan fakta yang menjadi acuan 4) merekonstruksi ulang proposisi-proposisi sesuai dengan fakta dari masing-masing kasus individu dan 5) mengulangi proses ini sesuai keperluan sampai batas kejenuhan.

\section{HASIL PENELITIAN DAN PEMBAHASAN}

Sesuai dengan hasil penelitian peneliti bahwa perencanaan pembelajaran Aqidah Akhlak dalam pendidikan karakter ini ada beberapa yang harus diperhatikan antara lain: (1) merancang perencanaan pembelajaran berdasarkan kurikulum yaitu berpedoman pada silabus dan RPP, (2) dalam perencanaan pembelajaran Aqidah Akhlak harus memperhatikan pemilihan bentuk pembelajaran yang disesuaikan dengan kondisi, karakteristik dan kemampuan siswa, agar pembelajaran berlangsung sesuai tujuan yang diharapkan.

Perencanaan pembelajaran Aqidah Akhlak yang dibuat oleh guru adalah penyusunan perencanaan penggunaan media pembelajaran dan bentuk belajar yang berdasarkan pada tujuan. Di mana tujuan pembelajaran itu selain dapat menambah ilmu pengetahuan dari siswa itu sendiri, tetapi juga dapat mengubah perilaku mereka agar menjadi pribadi yang lebih baik. Ini mengacu pada pengertian belajar yang dikemukakan oleh Kimble dan Garmezi 
bahwa belajar adalah perubahan tingkah laku yang relatif permanen yang terjadi sebagai hasil dari pengalaman. Untuk itu perencanaan yang disusun oleh guru disesuaikan dengan kondisi, karakteristik dan kemampuan siswa, akan tetapi tetap berpedoman pada kurikulum pembelajaran yaitu berdasarkan pada silabus dan RPP.

Dengan dilakukannya perencanaan yang disusun oleh guru maka proses pembelajaran akan berjalan sesuai dengan tujuan yang diharapkan, yaitu siswa mampu menguasai materi dan mereka dapat menerapkan materi yang disampaikan dalam kehidupan siswa sehari-hari sehingga terbentuklah karakter yang baik. Di dalam sebuah perencanaan tidak terlepas dari media, strategi dan pengkondisian suasana kelas yang dilakukan oleh guru saat proses pembelajaran berlangsung. Peran guru di sini adalah sebagai fasilitator dan motivator bagi siswanya. Untuk itu peran guru sangat berpengaruh dalam pembentukan karakter siswa. Untuk itu, guru harus mampu membuat perencanaan pembelajaran yang berkualitas dan semenarik mungkin, agar para siswa termotivasi untuk lebih baik dalam meningkatkan belajarnya.

Penerapan pembelajaran Aqidah Akhlak mengacu pada tata tertib maupun aturan yang telah ditetapkan dalam setiap kegiatan atau proses pembelajaran dalam suatu lembaga pendidikan, di antaranya proses pembelajaran dengan mengacu pada kurikulum maupun silabus dari masing-masing materi pelajaran yang telah ditetapkan oleh pemerintah. Sehingga dari pihak sekolah tinggal mengolah, membuat program atau rencana pembelajaran Aqidah Akhlak dengan tetap mengacu pada kurikulum maupun silabus yang ada.

Penerapan pembelajaran Aqidah Akhlak ini ditujukan pada pembentukan karakter siswa. Siswa tidak hanya memperdalam dari segi keintelektualannya saja, akan tetapi juga pada karakter atau pribadi siswa. Untuk itu dalam penerapannya guru harus mampu memberikan pembelajaran yang bermakna saat proses pembelajaran berlangsung. Guru menggunakan berbagai macam sumber belajar dengan mengaitkannya dengan materi yang dipelajari. Selain itu keaktifan siswa dalam proses pembelajaran juga haru diperhatikan karena ini dapat dijadikan ukuran guru sejauh mana siswa mampu memahami materi Aqidah Akhlak.

Pembelajaran secara konsepsional ini memiliki beberapa implikasi. Pertama, perlu diusahakan agar proses pembelajaran yang dilakukan berlangsung secara interaktif antara siswa dengan sumber belajar yang direncanakan. Kedua, bagi siswa, dalam pembelajaran dapat berlangsung interaksi internal yang melibatkan seluruh potensi yang dimilikinya dengan sumber belajar. Sumber belajar sendiri cukup beragam; (1) nilai-nilai yang ada dalam mata pelajaran yang sedang diajarkan; (2) guru yang berfungsi sebagai fasilitator; (3) bahan ajar cetak maupun non cetak; (4) media dan alat yang dipakai belajar; (5) cara dan teknik belajar yang dikembangkan; (6) kondisi lingkungan (sosial, budaya, spiritual, dan alam) yang menghasilkan perubahan tingkah laku siswa ke arah yang lebih dewasa.

Ketiga, dalam proses itu juga terbuka peluang untuk memilih, menetapkan, dan mengembangkan metode pembelajaran yang memiliki peluang paling baik bagi tercapainya tujuan. ${ }^{57}$ Pembentukan karakter pada siswa

57 Muhaimin, dkk, Paradigma Pendidikan Islam, Upaya Mengefektifkan Pendidikan Agama Islam di Sekolah. (Bandung: Remaja Rosdakarya, 2001), hlm 33 . 
dalam proses pembelajaran ini pun mengacu pada pendapat dari Marzuki bahwa karakter identik dengan akhlak, sehingga karakter merupakan nilai-nilai perilaku manusia yang universal yang meliputi seluruh aktivitas manusia, baik dalam rangka berhubungan dengan Tuhan, dengan diri sendiri, dengan sesama manusia, maupun dengan lingkungan, yang terwujud dalam pikiran, sikap, perasaan, perkataan, dan perbuatan berdasarkan normanorma agama, hukum, tata krama, budaya, dan adat istiadat. ${ }^{58}$ Telah dijelaskan bahwa di dalam pendidikan karakter itu terdapat nilai-nilai yang terkandung di dalamnya dan hal tersebut harus benar-benar bisa ditanamkan pada semua siswa di sekolah.

Penerapan evaluasi tujuannya dalam penyampaian pembelajaran Aqidah Akhlak dalam pembentukan karakter siswa. Berdasarkan pengamatan hasil dari evaluasi penerapan pembelajaran Aqidah Akhlak yang dilakukan oleh guru dapat meningkatkan prestasi belajar siswa dan perubahan karakter pribadi siswa. Hal ini dapat diketahui dari nilai rata-rata siswa dari masing-masing kelas di kedua lokasi penelitian berdasarkan dari studi dokumentasi, observasi dan wawancara yang dilakukan peneliti, yaitu di MIN Sekuduk dan MIN Pemangkat. Dalam evaluasi pembelajaran ini tidak terlepas dari nilai-nilai karakter yang ditanamkan pada siswa di sekolah yang erat kaitannya dengan pembelajaran Aqidah Akhlak. Pembentukan kepribadian yang utuh pada siswa diimplementasikan dalam kehidupan siswa. Selain itu faktor lingkungan sangat berpengaruh terhadap pembentukan karakter siswa. Penilaian yang dilakukan guru ini tidak

58 Marzuki,Pengintegrasian Pendidikan Karakter dalam Pembelajaran di Sekolah. (Yogyakarta: FIS Universitas Negeri Yogyakarta, 2015), hlm 11. hanya pada penilaian tertulis dari tugas siswa, tetapi juga pada penilaian sikap yaitu melalui buku kontrol yang digunakan guru untuk mengetahui perilaku siswa saat di sekolah maupun di rumah.

Berdasarkan hasil penelitian, prestasi belajar Aqidah Akhlak siswa di kedua lokasi penelitian tersebut meningkat setelah diimplementasikannya pembelajaran Aqidah Akhlak dalam pembentukan karakter siswa oleh masing-masing guru mata pelajaran Aqidah Akhlak. Nilai rata-rata mata pelajaran Aqidah Akhlak perkelas menunjukkan di atas nilai Kriteria Ketuntasan Minimal (KKM) mata pelajaran Aqidah Akhlak kelas V.

Hal tersebut menunjukkan bahwa implementasi pembelajaran Aqidah Akhlak yang dilakukan oleh guru mata pelajaran dari masing lokasi penelitian tersebut membuahkan hasil. Dengan demikian implementasi pembelajaran Aqidah Akhlak dapat digunakan sebagai upaya pembentukan karakter siswa yang telah direncanakan secara efektif dan efisien.

\section{KESIMPULAN}

Berdasarkan hasil penelitian yang disimpukan ini dikemukakan beberapa implikasi yang dianggap relevan dengan penelitian, antara lain sebagai berikut.

a. Perencanaan pembelajaran guru Aqidah Akhlak sebagai upaya pembentukan karakter adalah dengan mendesain perencanaan pembelajaran dengan melibatkan media. Rancangan perencanaan dalam penyampaian pembelajaran Aqidah Akhlak yang dibuat oleh guru adalah penyusunan perencanaan penggunaan media pembelajaran dan bentuk belajar yang berdasarkan pada 
tujuan. Dalam memilih media dan metode pembelajaran, pada dasarnya prinsip yang digunakan guru adalah efektifitasnya dalam mencapai tujuan pembelajaran. Rancangan bentuk belajar di kelas yang dirancang guru adalah untuk menciptakan kondisi agar siswa dapat belajar dengan penuh motivasi.

b. Penerapan pembelajaran guru Aqidah Akhlak dalam upaya pembentukan karakter siswa yang dilakukan telah mengacu pada tata tertib maupun aturan yang telah direncanakan dan ditetapkan dalam setiap kegiatan atau proses pembelajaran di suatu lembaga pendidikan. Penyampaian pembelajaran Aqidah akhlak dalam pembentukan karakter siswa yang diterapkan oleh guru mata pelajaran dari masing-masing lokasi penelitian tersebut membuahkan hasil. Nilai rata-rata mata pelajaran Aqidah Akhlak perkelas menunjukkan di atas nilai Kriteria Ketuntasan Minimal (KKM). Dengan demikian media dan metode yang digunakan dalam penyampaian pembelajaran dapat digunakan sebagai upaya meningkatkan prestasi belajar siswa dan sebagai upaya untuk pembentukan karakter siswa terutama pada pada mata pelajaran Aqidah Akhlak.

c. Evaluasi pembelajaran guru Aqidah Akhlak biasanya berupa ujian tugas dari guru, ulangan harian, nilai UTS dan ulangan UAS siawa. Penyampaian pembelajaran Aqidah Akhlak dalam pembentukan karakter siswa yang diterapkan oleh guru mata pelajaran dari masing-masing lokasi penelitian tersebut membuahkan hasil. Nilai rata-rata mata pelajaran Aqidah Akhlak perkelas menun- jukkan di atas nilai Kriteria Ketuntasan Minimal (KKM). Dengan demikian media dan metode yang digunakan dalam penyampaian pembelajaran dapat digunakan sebagai upaya meningkatkan prestasi belajar siswa dan sebagai upaya untuk pembentukan karakter siswa terutama pada pada mata pelajaran Aqidah Akhlak.

\section{DAFTAR PUSTAKA}

Abdullah bin, Abdil Hamid al-Atsari. Panduan Aqidah Lengkap, Bogor: Pustaka Ibnu Katsir, 2005.

Aly, Hery Noer dan Munzier. Watak Pendidikan Islam, (Jakarta Utara: Friska Agung Insani, cet. III, , 2008.

Azzet, Akhmad Muhaimin. Urgensi Pendidikan Karakter di Indonesia, Yogyakarta: ArRuzz Media, 2001

Kesuma, Dharma dkk. Pendidikan Karakter Kajian Teori Dan Praktek di Sekolah. Bandung: PT Remaja Rosdakarya, 2011..

Marzuki. Pengintegrasian Pendidikan Karakter dalam Pembelajaran di Sekolah. Yogyakarta: FIS Universitas Negeri Yogyakarta, 2015.

Muhaimin, dkk. Paradigma Pendidikan Islam, Upaya Mengefektifkan Pendidikan Agama Islam di Sekola. Bandung: Remaja Rosdakarya, 2001.

Mujib, Abd, Muhaimin Tadjab. Dimensi-Dimensi Studi Islam. Surabaya: Karya Abditama, 1994.

Parsons, Les. Bullied Teacher Bullied Student, terj. Grace Worang, Jakarta: Grasindo, 2009.

Samani, Muchlas Dan Hariyanto, M.S. Konsep Dan Model Pendidikan Karakter. 
Purniadi Putra

Bandung: PT Remaja Rosdakarya Offset, 2011.

Sukmadinata, Nana Syaodih. Metode Penelitian Pendidikan. Bandung: PT Rosda Karya, 2007.

Wibowo, Agus. Pendidikan Karakter: Strategi Membangun Karakter Bangsa Berperadaban, Yogyakarta: Pustaka Belajar, 2012. 